\title{
News from the field: Visual planning and urbanism in the mid-twentieth century conference, Newcastle, UK, 11-13 September 2007
}

\section{Erdem Erten}

To cite this article: Erdem Erten (2008) News from the field: Visual planning and urbanism in the mid\#twentieth century conference, Newcastle, UK, 11-13 September 2007, Planning Perspectives, 23:3, 397-400, DOI: 10.1080/02665430802102856

To link to this article: http://dx.doi.org/10.1080/02665430802102856

\section{Published online: 16 Jun 2008.}

Submit your article to this journal 지

\section{Џ Article views: 44}

\section{Q View related articles $\longleftarrow$}


Planning Perspectives, 23 (July 2008) 397-400

\title{
IPHS SECTION
}

\section{News from the field: Visual planning and urbanism in the mid-twentieth century conference, Newcastle, UK, 11-13 September 2007}

\author{
ERDEM ERTEN \\ Department of Architecture, Izmir Institute of Technology, Gulbahce Campus, Urla 35430, Izmir, \\ Turkey (e-mail:erdemerten@iyte.edu.tr)
}

While the understanding of planning or urban design through their visual aspects alone would be reductive, attitudes to planning that focus on visual and three-dimensional modes remain understudied. To fill this gap, a conference entitled, 'Visual planning and urbanism in the mid-twentieth century', was held in Newcastle on 11-13 September 2007. The conference focused on 'a strand of more practical urbanism, modernist in flavour but historically informed [which sought] to recover positive conceptions of the city and town after the perceived deprivations of the nineteenth century'. The topics discussed at the conference papers focused upon the modern period, during which planners sought to rethink cities radically - as evidenced by such interventions as the CIAM doctrine codified by the Athens Charter, Ebenezer Howard's Garden City, the de-urbanist proposals contained within Frank Lloyd Wright's Broadacre City, or interpretations of the linear city by Okhitovich and Milyutin - but also remained critical of drastic restructuring.

The conference was planned as part of the 'Town and townscape: the work and life of Thomas Sharp' project. Sharp (1901-78) was a significant voice within the post-1930s debates on the development of, and threats against, the town and the countryside. Produced on the eve of post-Second World War reconstruction, his plans for historic cities such as Oxford, Exeter and Durham (most published by The Architectural Press in book form) were seminal in the development and dissemination of townscape as urban design and town planning pedagogy and in setting precedents for the planning profession in the UK and beyond. Accompanied by an exhibition of Sharp's personal papers, drawings and books catalogued and conserved in the collection by the project, the conference also presented an opportunity to introduce scholars to this unique collection [1]

The first day opened with the keynote speech of Heleni Porfyriou (Centro di Conservazione delle Opere d'Arte, Rome), entitled 'The legacy of Camillo Sitte from civic art to visual planning'. Recontextualizing Sitte's oeuvre with reference to the scientific foundations that 
governed his analytical studies on cities and human vision by the end of the nineteenth century, Porfyriou provided a historical introduction to visual planning. She noted that epistemological discoveries in the field of subjective vision had a fundamental influence on Sitte's formulation of an art of urban space and not mere aesthetic preference. Addressing the uninformed criticism that dismissed the work of Sitte as dependent on scenographic arrangement, Porfyriou argued that Sitte was interested in 'the act of seeing', that is 'the physiological mechanism that gives rise to the perception of space on which all architectural effects are based'.

Michael Hebbert and Andrew Crompton (Manchester University) followed Porfyriou's talk with a historical re-evaluation of pictorial composition in British architectural practice. Examined via 'sketchbooks of collages of details and scenes', they argued that such practices and the knowledge acquired through them, remain as valuable for the design of urban spaces as for theoretical explorations in the field of architectural education. Jos Bosman (Eindhoven University of Technology) evaluated the 'German stadtbild discussion applied to English pastoral imagery' and 'the visual role of modern architecture in a cityscape with historical fragments' in the work of Werner Hasper in Kassel and of Rudolph Schwarz in Cologne. Nicholas Bullock (Cambridge University) discussed French architect Gaston Bardet and his supporters' opposition to CIAM in France. Bardet's vigorous and successful antagonism to Le Corbusier's urbanism demanded a reconciliation of modernism with older French traditions and the conservation of heritage. By presenting an alternative approach in journals such as Architecture Française and Urbanisme, Bardet acquired considerable influence in French post-war reconstruction, according to Bullock.

The following session was dedicated to Italian post-WWII reconstruction. In contrast to the rest of Europe, where the rift widened between planning and architecture, the papers argued that among architects in Italy there was a growing awareness of the need for a unified approach to architecture and town planning that was also structurally, functionally and morphologically flexible. Francesca Bonfante and Christina Pallini (Politectecnico di Milano) noted that after WWII a wealth of theoretical work was produced in response to the urgency of maintaining the historical fabric of cities, for which the idealized planning criteria of the Modern Movement and other radical models remained a threat. Filippo de Pieri (Politecnico di Torino) focused on the increased use of visual media in promoting urban conservation and its simultaneous contribution to redefining national identity. Eamon Caniffe (Manchester Metropolitan University) concluded the session by pointing to a largely unproductive division between those who saw the potential of the Italian urban environment for the purposes of tourism and those who claimed to see beyond that, like the adherents of Team X.

The two sessions dedicated to work on Thomas Sharp concluded the first day. Kathy Stansfield (now editor of The Structural Engineer), author of the only MA thesis on the life and work of Sharp, a version of which was published as a chapter in Gordon Cherry's Pioneers in British Planning [2], presented her personal reflections and set the stage for Stephen Ward's elaborate assessment of Sharp's planning career. In his keynote speech, Ward (Oxford Brookes University) pointed to the need for repositioning Sharp more centrally in the history of the planning discipline and profession, especially in the 1930s and 1940s. According to Ward, British planning history told largely in terms of the Garden City and modernism is far from doing justice to Sharp, although his critical impact on both camps is visible. John Pendlebury (Newcastle University, director of 'Town and townscape: 
the work and life of Thomas Sharp' project) added that although visual planning was central to Sharp's approach he was antagonistic towards the Garden City and suburb as well as towards social segregation and functional zoning. Sharp privileged the pedestrian, mixed use and the street as the urban building block, principles which seemed anachronistic at the time but have become commonplace now. Peter Larkham (Birmingham University) argued that Sharp's emphasis on the conservation of urban character, which also made him unfit for the modernist camp, came into conflict with local and national priorities at the time when Chichester was planned. Erdem Erten (Izmir Institute of Technology) presented the results of his research on the Sharp collection, which focused on Sharp's close collaboration with The Architectural Review and The Architectural Press. Erten argued that Sharp's collaboration with $\mathrm{H}$. de C. Hastings (editor of the magazine and half-owner of the press), especially during the publication of his plans for Durham, Exeter, Oxford and Salisbury by The Architectural Press, was crucial in the development and dissemination of 'Townscape'.

The second day was directed towards reflections on visual planning attitudes in the wider international scene and the impact of Townscape. Nadia Fava,(University of Girona) introduced her research on Leon Jaussely's Romulus plan for Barcelona of 1905. Fava argued that Jaussely's plan accompanied by 21 perspectives depicting the quality of urban space provided one of the earliest examples of Sitte's principles put into practice. Andrea Yuri Urushima (Kyoto University) and Keiichi Kobayashi (Tohoku University) discussed the echoes of 'Townscape' in Japanese urbanism. Urushima focused on Uzo Nishiyama's role in opposing mainstream planning currents and his distrust of grandiose modernist planning schemes, while looking for alternative approaches to city form.

Monica K. Bhargava (Centre of Built Environment in Calcutta) presented Gordon Cullen's work for Calcutta (now Kolkata) in the 1960s. Bhargava, a collaborator of Santosh Gosh who worked with Cullen at the time, showed unpublished sketches of Cullen to illustrate his townscape proposals for the city. Looking closely at the conflict between Denys Lasdun and Thomas Sharp that emerged after Lasdun's proposals for tower blocks in Cambridge, Barnabas Calder shed more light on the antagonism between advocates of New Brutalism and those of Townscape. Calder argued that this antagonism was not as radically apparent in the New Brutalists' design principles and that they were more indebted to Sharp and his contemporaries than they would acknowledge.

The title of Eleanor Smith Morris' (Commonwealth Human Ecology Council) paper 'Is New Urbanism almost all right? alluded to Robert Venturi's remarks on American Main Street. The affinities that Morris established between Thomas Sharp's approach and New Urbanism sparked discussion in the audience on whether Sharp would have approved of New Urbanism. Aidan While and Malcolm Tait (University of Sheffield) demanded a reassessment of Sharp's response to Princesshay, Exeter, for the benefit of contemporary conservation practice. They argued that Sharp's plan still has valuable lessons in reconciling the demands of reconstruction and pedestrian experience with the memory of the blitzed city. Adding the final touch of theory, Andrew Law (Newcastle University) argued that the language of Townscape in the writings of Thomas Sharp shares an 'Anglo-American romantic language of organicism and landscape that has its roots in a philosophical and ideographic movement of the late nineteenth and early twentieth century'. Law warned that Sharp's language sometimes borders on an 'urban organic essentialism' connected to a 'twentieth century imaginary of the urban as a living organism that could be growing in 
both "healthy" and "unhealthy" ways'. The second day ended with an open forum for discussion that allowed the audience and the participants to add concluding remarks

In the final day of the conference, participants chose one of two field trips that focused on two important chapters of Sharp's planning career. While one party visited Durham, the spectacular cathedral city of the north for which Sharp's plan was published in 1945, the second party visited a number of villages of northern England analysed for his classic 'The Anatomy of the Village' (1946). This visit also included the village at Kielder, built and realized only partially according to Sharp's designs for the Forestry Commission, and inspired by Sharp's studies for this book.

Although most historical work still concentrates on ideas on improving the 'functional performance' of the city or the post-war 'neo-avant-garde', these histories can be made more meaningful when they are complemented by recent research on alternative positions, developed in response to emergent problems in planning, notably the need for conservation in reconstruction and to mediate the pressures of a modern, technology-driven society. The papers delivered at this conference suggested considerable possibilities for the development of such alternative historical narratives. It is hoped that the results will soon be disseminated to a wider audience in the form of various publications.

\section{Notes and references}

1. Among the materials stored in the University of Newcastle's Special Collections are a catalogue, a brief biography of Sharp, an annotated bibliography of Sharp's published writings and plans. A finding aid for other publicly accessible Sharp material can be accessed under www.archiveshub.ac.uk . For more information see www.ncl.ac.uk/library/sharp/index.php.

2. Kathy Stansfield, Thomas Sharp 1901-1978, in Gordon Cherry (ed) Pioneers in British Planning. London: The Architectural Press, 1981, 150-76. 